\title{
Perspective
}

\section{Agriculture 4.0: Is Sub-Saharan Africa Ready?}

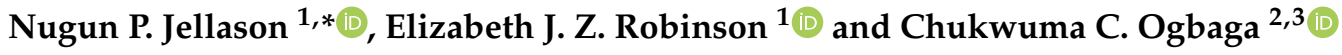 \\ 1 School of Agriculture, Policy and Development, University of Reading, Reading RG6 6EU, UK; \\ e.j.robinson@reading.ac.uk \\ 2 Department of Biological Sciences, Nile University of Nigeria, Airport Road, Abuja 900001, Nigeria; \\ chukwumaogbaga@gmail.com \\ 3 Department of Microbiology and Biotechnology, Nile University of Nigeria, Airport Road, \\ Abuja 900001, Nigeria \\ * Correspondence: n.p.jellason@reading.ac.uk
}

Citation: Jellason, N.P.; Robinson,

E.J.Z.; Ogbaga, C.C. Agriculture 4.0:

Is Sub-Saharan Africa Ready?. Appl. Sci. 2021, 11, 5750. https://doi.org/ $10.3390 /$ app 11125750

\section{Academic Editors:}

Ginés García-Mateos,

Dolores Parras-Burgos and José Miguel Molina Martínez

Received: 28 April 2021

Accepted: 18 June 2021

Published: 21 June 2021

Publisher's Note: MDPI stays neutral with regard to jurisdictional claims in published maps and institutional affiliations.

Copyright: (c) 2021 by the authors. Licensee MDPI, Basel, Switzerland. This article is an open access article distributed under the terms and conditions of the Creative Commons Attribution (CC BY) license (https:// creativecommons.org/licenses/by/ $4.0 /)$

\begin{abstract}
A fourth agricultural revolution, termed agriculture 4.0, is gradually gaining ground around the globe. It encompasses the application of smart technologies such as artificial intelligence, biotechnology, the internet of things (IoT), big data, and robotics to improve agriculture and the sustainability of food production. To date, narratives around agriculture 4.0 associated technologies have generally focused on their application in the context of higher-income countries (HICs). In contrast, in this perspective, we critically assess the place of sub-Saharan Africa (SSA) in this new technology trajectory, a region that has received less attention with respect to the application of such technologies. We examine the continent's readiness based on a number of dimensions such as scale, finance, technology leapfrogging, institutions and governance, education and skills. We critically reviewed the challenges, opportunities, and prospects of adopting agriculture 4.0 technologies in SSA, particularly with regards to how smallholder farmers in the region can be involved through a robust strategy. We find that whilst potential exist for agriculture 4.0 adoption in SSA, there are gaps in knowledge, skills, finance, and infrastructure to ensure successful adoption.
\end{abstract}

Keywords: agriculture 4.0; internet of things (IoT); precision agriculture; robotics; smallholders; sub-Saharan Africa (SSA)

\section{Introduction}

Agricultural systems across the globe have evolved over the years. The literature identifies a "first agricultural revolution" or "Agriculture 1.0" [1-4], that involved hunting, gathering and settled farming; and a "second agricultural revolution", or the British agricultural revolution [5], in the 18th century, which saw an increase in agricultural production due to improved land productivity from mechanised agriculture [3]. Agricultural systems then evolved as a "third" Asian Green Revolution was introduced with a technology package of hybrid seeds, irrigation, modern pest control and synthetic fertilisers [6] in the 1960s; and more recently to what is termed agriculture $4.0[7,8]$, the "fourth agricultural revolution". Agriculture 4.0, a recent and potentially game-changing transition lacks a universally accepted definition. However, it encompasses the adoption of high technology (High-Tech) solutions such as the internet of things (IoT), biotechnology innovations, cloud computing, precision agriculture, smart farming, drones, sensors, and robotics [9-13]. It is also underpinned by the idea of sustainable intensification, covering concepts that are in line with sustainable food production and better agricultural systems [14,15].

The Asian Green Revolution, which ended in 1990, has been credited with resolving food crises, reducing poverty and offering potentially important lessons for sub-Saharan African (SSA) countries [16]. Yet, the Asian Green Revolution has also proven to be controversial. Criticisms include the inability of smallholder farmers to compete with larger farms, which led to increased inequality amongst farmers; and an increase in fertiliser use that led to eutrophication of streams and lakes [17-19]. 
Taking a cue from the Asian Green Revolution, African agriculture policymakers, with the support of donors like the Bill and Melinda Gates Foundation, the Rockefeller Foundation, UK Aid, the United States Agency for International Development (USAID) and the Mastercard Foundation, proposed an African Green Revolution where improved seeds and fertilisers were to drive this process $[20,21]$. This led to the creation of the Alliance for a Green Revolution in Africa (AGRA) in 2006 [22]. The broad goals of AGRA were to provide African smallholder farmers with high-yielding agricultural practices that would allow them to double their yields [18]. Yet to date the evidence suggests that this, albeit ambitious, target has not been achieved. Critics variously suggest that AGRA did not achieve its goals due to the lack of consultations with farmers; the imposition of Western-type technologies not appropriate for SSA's farming systems; high input costs that were not offset by sufficiently high yields; and a focus on chemical-intensive monoculture cropping that leads to loss of crop and diet diversity [22].

This article assesses the challenges and prospects for agriculture 4.0 adoption in SSA. Most of the literature addressing agriculture 4.0 takes a higher-income country (HIC) viewpoint. To the best of our knowledge, few works exist on this topic from an SSA perspective, and only some of the technologies associated with agriculture 4.0 that have been introduced in higher-income countries appear to be being implemented in SSA [12]. In Section 2 we consider the potential of agriculture 4.0 technologies in SSA, by focusing on characteristics of the region, and of the technologies. We explore SSA's readiness for, and ability to embrace, agriculture 4.0, focusing on the challenges and opportunities for SSA's farmers to tap into the agriculture 4.0 revolution. In Section 3, we explore how SSA can leverage the opportunities for adopting agriculture 4.0. Finally, Section 4 concludes, by reflecting on the implication of SSA losing out in the new wave of an agricultural revolution.

\section{Prospects and Challenges for Agriculture 4.0 Adoption in Sub-Saharan Africa}

Agriculture in SSA is mostly rainfed, and in many countries is dominated by smallholder farmers who tend to have low levels of irrigation [23], and face biophysical and institutional challenges on top of the recent neglect of the sector [24]. These challenges include lack of insurance [25] and inefficient credit markets [26,27]; degraded soils, biodiversity loss [28]; and climate change [29-31]. Together these challenges exacerbate efforts to reduce food insecurity [7,32].

Different strategies have been employed by smallholder farmers across SSA to tackle these various challenges. For example, sustainable intensification of agriculture using new technologies has been highlighted in the literature as essential for producing additional food without reducing biodiversity and other ecosystem services [11,33]. In some African countries, this has included the promotion and adoption of integrated pest management, conservation agriculture, agroforestry, and system improvements [34,35]. Conservation agriculture (CA) which involves minimum tillage, diversified crop rotations and soil surface cover has been widely practiced in southern parts of Africa [36-38]. This broad suite of technologies and practices has economic (such as reduced labour requirements), agronomic (such as improved water conservation), and environmental (such as reduced soil erosion) benefits. These practices also reduce soil degradation and improve climate change management through carbon sequestration.

To address a lack of irrigation in arid and semi-arid areas, in the western SudanoSahelian zones, rainwater harvesting techniques such as Zai (planting pits) are utilised in Burkina Faso [39]; in northern Nigeria, integrated crop-livestock systems in a circular economy act as insurance against failure of one system and at the same time, improve the water holding capacity of soils for efficient food production [40,41]. In eastern Africa, genetically modified (GM) water-efficient maize seed has been promoted among smallholder farmers by the International Maize and Wheat Improvement Centre (CIMMYT) in partnership with Monsanto PLC to adapt to rainfall variability [42]. Finally, farmers in SSA do increasingly have access to rural micro, small and medium-sized enterprises (MSMEs) 
that seek to provide financing [26], better credit, and weather-indexed-based insurance against climate variability [25].

In the rest of this section, we explore the extent to which agriculture 4.0 technologies can complement, replace or improve upon these and other strategies that focus on sustainable increases in agricultural production; the scarcity of natural resources; adapting to climate change; and avoiding food waste $[4,14]$. We first consider scale, in particular, the reality that many farmers in SSA are smallholders, many intercrop, and within-field crop diversity is common, which may hinder the broad adoption of agriculture 4.0 technologies [43]. Second, we focus on finance, the reality that agriculture 4.0 technologies tend to be financially intensive [19], and the historically poor access to capital that smallholder farmers in SSA have faced. Our third area of exploration is the extent to which African countries have the digital infrastructure in place. Fourth, we address the institutions, governance, and ethics surrounding agricultural technology adoption; and finally, we explore the extent to which Africa's farmers have the education and skills needed to embrace agriculture 4.0.

\subsection{Scale}

Smallholders continue to dominate agriculture in SSA, with $80 \%$ of agricultural output produced by farmers with landholdings less than 2 hectares on average, [27]. Some scholars have suggested that improvements in agricultural productivity in SSA, just like in the case of the Asian Green Revolution, are likely to be driven by smallholders who currently control most of the landholdings [44]. Others have argued that relying on the conventional smallholder model of agriculture is inefficient because African smallholder productivity is very low, e.g., [20,45]. Either way, understanding the scale at which agriculture 4.0 technologies are likely to operate is particularly important for SSA; and the reality is that, at least in the short to medium term, smallholder farmers will remain important in the sector.

Agriculture 4.0 has often been associated with large-scale farming $[13,46]$. For example, unmanned aerial vehicles (UAVs) are increasingly being used for fertilisers and chemical spraying. UAVs, in combination with smartphone platforms to provide remote sensing data, also use global positioning systems (GPS) for digital soil mapping $[10,11,14,15]$ for various environmental and agricultural development purposes [47]. However, uptake of this technology was reported in a South African study to be low [47].

Modalities already exist in SSA where smallholder farmers could rent these or similar services or jointly source such "lumpy" technologies, thereby overcoming any "scale" constraint. For example, in recent years, SSA countries have seen elements of the 'fourth agricultural revolution' technology such as the mobile application for tractor hiring being promoted by international organisations including the International Crops Research Institute for the Semi-Arid Tropics (ICRISAT) and the private sector [12]. One specific example is a blockchain-enabled application that links tractor providers and smallholder farmers to promote agricultural mechanisation [48]. This application, called Hello Tractor, is a software that provides a platform for renting tractors for land cultivation from owners by smallholders. More broadly, ICRISAT's innovation Hub (iHub) has been developed to support activities along the crop production value chains from seed certification, product manufacturing and retail [49], many of which are scale neutral and as such could be of direct benefit to smallholder farmers in SSA.

Agriculture 4.0 technologies could have an important role in African countries where fertiliser use has long been low [50], despite many initiatives to increase its use. For example, in June 2006, the African Union (AU) member states' Ministers of agriculture, at a summit in Abuja, Nigeria, resolved to increase the level of fertiliser use from 8 to $50 \mathrm{~kg}$ per hectare on average by the year 2015. This was despite a lack of scientific evidence to support the value of such an arbitrary increase [51], prompting concerns that the move would likely be counterproductive, leading to an increased cost of production. Agriculture 4.0 technologies such as soil mapping for soil analysis could offer more sustainable alternatives 
by identifying areas of nutrient deficiencies to inform precision fertiliser application that is cost-efficient and environmentally sound [14].

Remote sensing data has long been used in agriculture, whether to simply map cropland, or to determine biomass, yields, and crop stress [52]. Further, it is becoming more affordable, in part due to the availability of free high-resolution satellite imagery. Digital soil mapping has the potential to identify the location of high-value agricultural land by providing detailed information on soils and is already being used in SSA [47]. However, the scale and heterogeneity of Africa's agricultural landscapes are likely to continue to pose challenges, particularly for smallholder farmers [43]. For example, Lowder, Skoet [27] highlight, in particular, the difficulty of using satellite data to determine crop yields in smaller farms.

The livestock sector has experienced its own "revolution", which has paralleled what has been referred to as "Industry 2.0", the mass production of goods to increase productivity [3]. Particularly in higher-income countries, livestock farming has shifted away from home-based animal husbandry towards intensive, often large-scale, farming [3]. Agriculture 4.0 technologies can be found in, for example, livestock monitoring and biosensing, which can be used to detect and identify infectious diseases, drug residues, and ovulation prediction [53]. Many of these technologies are linked to intelligent animal health monitoring systems, in which animals may wear the technology [3]. Agriculture 4.0 approaches have also been linked to ecologically friendly efficient farming approaches, that could include monitoring emissions from livestock [54].

In many SSA countries, the scale and intensity of the livestock sector differ considerably from the large-scale farming found in HICs. However, although in some higher-income countries per capita consumption of meat is plateauing or even falling, in SSA and other low- and middle-income countries (LMIC), consumption continues to increase, with pork, beef, and chicken being the most consumed meats [54], and with this increase in consumption comes increases in GHG emissions. This suggests that in the future, agriculture 4.0 technologies relevant to livestock will be increasingly important for SSA.

\subsection{Finance and Capital for Investment, Research and Development}

Financial constraints and poor literacy are likely to affect the uptake of agriculture 4.0 technologies. Much of SSA's low-income rural population works in highly uncertain environments, with little access to capital, input and output markets, or crop insurance. These realities limit the ability of smallholder farmers to invest in "modern" technologies, especially those requiring upfront high-cost investments [55]. In addition, investment in agricultural research and development $(\mathrm{R} \& D)$ as a percent of agricultural gross domestic product (GDP) in SSA is relatively low at $0.38 \%$ (2001-2013 average) and falling, and considerably lower than other regions in the world when measured per hectare of cropland or per agricultural labourer [7]. Importantly for agriculture 4.0, a digital infrastructure funding gap of about one billion euros exists in SSA [25]. This suggests a high degree of underfunding of agricultural research in Africa [24] with implications for technology adoption.

Efforts by African governments to increase investments in agriculture are yet to reach targeted goals. For instance, the African governments launched the Comprehensive African Agricultural Development Program (CAADP) in 2006 that commits them to spend at least $10 \%$ of their total budget on agriculture by 2025. As of 2014, only Malawi, Zimbabwe and Mozambique had met or surpassed this target, with Zambia, Rwanda and Niger close to reaching the target [24]. And in 2017, only 20 out of the 47 reporting African Union (AU) countries remained on track to meet the 2025 commitments [25].

Agriculture 4.0 technologies are generally perceived to be financially intensive [11], thereby making their deployment likely to be difficult for Africa's smallholder farmers. For example, "next-generation" nanosensor technology is being used to increase sustainable food production and better agricultural system in the United States of America and Australia [56,57]. A fast speed method has recently been shown to increase chloroplast 
transformation in vitro with the potential of improving crop yields for crops such as arugula, watercress, spinach and tobacco [56]. These same technologies are being used for plant phenotyping and disease monitoring in the field [58]. Yet their cost of deployment makes them currently almost certainly inaccessible to African smallholder farmers.

A study on the perception of Brazilian farmers regarding the adoption of agriculture 4.0 technologies such as precision agriculture integrated with data from remote sensors on smartphones found that the cost of the machines, software, equipment and connectivity was a constraint to adoption [59]. More generally, capital availability has also been found to be a pre-requisite to the adoption of conservation agriculture technologies, especially where new equipment is needed [60].

Financial and agricultural advisory services technology start-ups such as Esoko in Ghana, Farmcrowdy in Nigeria, and EcoFarmer in Zimbabwe, which offer farmer advice on input use, credit and weather-indexed insurance, have received considerable attention in SSA [25]. For example, tech start-ups in these areas received investments of about 335 million Euros in 2018 [25]. These investments will create employment opportunities and increase uptake of the digital technologies [25]. This also suggests that financing agriculture 4.0 technologies, whilst still a constraint, may be less so in the future.

\subsection{Leapfrog Technology Opportunities and Digital Infrastructure Availability}

The reality for many African countries has been poorly developed physical infrastructure, including a low density of fixed telephone landlines and physical bank branches. This might historically have constrained economic development. However, increasingly African countries have proven able to leapfrog these technologies. That is, rather than follow what might be considered traditional technology adoption pathways, taken earlier by HICs, African countries may be able to skip an intermediate technology stage.

Examples of this technology leapfrogging that have already occurred that have particularly benefitted smallholder farmers relate to telecoms and banking [61]. For example, many African countries have rapidly transitioned from having a very low penetration of fixed landlines and traditional bricks and mortar banking infrastructure to a relatively high proportion of households with access to mobile telephony and mobile banking. New and modern information and communication technologies (ICTs) have played critical roles in bridging key agricultural extension and development infrastructure gaps. The mobile money transfer service application, M-Pesa, was pioneered in Kenya by Vodafone and expanded into other SSA countries such as Tanzania and South Africa [62]. M-Pesa is transforming agriculture in SSA, in part by providing mobile payment systems to farmers that have enabled many to boost crop production and move out of subsistence agriculture [63] Other agriculture 4.0 mobile-technology-supported financial and agricultural technologies such as M-Farm and Esoko have been widely adopted in SSA countries such as Kenya and Ghana respectively [62]. Esoko provides farmers with daily market prices for many key agricultural crops, using Short Message Services (SMS) sent to farmers' mobile phones, in addition to information on weather, market situation and farming tips $[64,65]$.

Many agriculture 4.0 technologies rely on the fourth generation (4G) of broadband cellular network technology, cloud computing, and big data analytics. Around $60 \%$ of SSA smallholder farmers have access to mobile connection with an increasing network of 4G connections and Data Centres being developed in SSA [25], suggesting that Africa's farmers are, in this respect, relatively well placed to take advantage of mobile phone-driven agriculture 4.0 technologies, that could also leverage the breakthroughs already recorded in ICTs' adoption in SSA and leapfrog the conventional technologies in agricultural advisory and financial services provision for the underserved [25].

\subsection{Institutions, Governance, and Ethics}

Agriculture 4.0 will almost certainly change the way of work for farmers and the culture around traditional ways of farming [15], whether in higher or lower-income countries. Some scholars are already asking whether agriculture 4.0 is the way forward for society 
in general, expressing concern that the social and ethical implications of adopting such technologies have not received adequate consideration in the design and implementation processes $[6,13]$.

These concerns are likely to be just as relevant for African smallholder farmers as for those in higher-income countries, and indeed concerns over institutions, governance and the ethical implications of new technologies are nothing new. There have long been concerns over the ethics of hybrid seeds, and plant breeders' rights, e.g., [66]. Efforts to increase mechanisation in African farming have in the past been hampered by rentseeking through elite capture and the lack of access to spare parts [67]. And sustainable intensification of agricultural systems across African countries has been hampered by weak institutions, whether due to poorly functioning markets or property rights over land [68].

\subsection{Education and Skills}

Younger and more educated farmers have been found to be more likely to adopt agriculture 4.0 technologies [69], and more broadly farmers are likely to need ICT skills and capabilities to fully embrace agriculture 4.0 [70]. Yet farmers in SSA are less literate than those in HICs; farm workers less literate than non-farm workers [7,71], and many farmers lack the skills to operate sophisticated technologies and to collect and manage the high volume of data used to improve decision-making [72]. This suggests that lack of education and skills in data management as a barrier to agriculture 4.0 adoption is likely to be an issue in some African countries. The gap in the quality of education and the need for more training in Africa have previously been highlighted in several African Union Commission Policy frameworks, see [72-74].

\section{Going Forward: Opportunities for SSA to Tap into the Agriculture 4.0 Revolution}

\subsection{Reasons for Optimism}

The surge in food demand in SSA due to the rise in population and the demand for more nutritious food by an increasing number of middle-income families is leading to greater opportunities for smallholder farmers in SSA to improve their production and incomes through the diversification and enhancement of their production systems using agriculture 4.0 technologies [12]. More broadly, agriculture 4.0 technologies have the potential to increase job creation, improve the revenues of farmers, and increase selfsufficiency and food exports [75]. However, if this fourth revolution bypasses Africa's farmers, African countries are likely to increasingly deplete their available natural habitats or rely on food imports, to the detriment of valuable biodiversity, long-term food security status, rural livelihoods, and poverty reduction.

Smallholder farmers in SSA tend to operate on small patches of land, making use of family labour or 'community work parties' to cultivate their lands, with little access to credit or insurance, and with high uncertainty of weather around agro-climatic conditions, prices, and access to markets. Despite these challenges, there seems to be considerable scope for the adoption of agriculture 4.0 technologies in SSA. Already the continent has demonstrated leadership with regards to mobile banking and the use of mobile telephony for increasing market efficiency; and access to $4 \mathrm{G}$ networks is relatively good and growing. Also, funding for tech start-ups has received boosts recently from foreign investors and multinational organisations to bridge the funding gaps. Extension information is currently accessible to an increasing number of farmers through mobile applications [25]. However, more training to harness the benefits of ICT education is needed to consolidate these gains [72].

One overarching constraint for Africa's farmers is that many must deal with the multiple constraints of scale, finance, and poorly functioning institutions. Innovative approaches that deal with multiple constraints include the Hello Tractor application that addresses scale and lumpy investments associated with mechanisation, access to credit and rental markets for machinery, and takes advantage of mobile supported technologies. Similarly, African farmers are benefiting from access to soil mapping, aerial chemical and 
fertiliser applications, that combine large and small-scale technology, and that increase the productivity and income of smallholder farmers. Yet overall technology adoption is still very limited across the continent, for example, the use of tractors remains low, leading to poor productivity and low yields [7]. As such, it is imperative to consider the potential of site-specific technology adoption to fill the low yield gap experienced in SSA [44].

Agriculture 4.0 suites of technologies may find application in an SSA context when smallholder farmers organise themselves into clusters. Clustering can promote interaction with stakeholders along agricultural value chains and has been shown to enhance the adoption of technology [76]. Clustering can also ensure that technology companies can be profitable when they deploy the agriculture 4.0 technologies for the benefit of smallholder farmers due to the advantage of scale, compared to dealing with individual farmers working on less than a hectare on average [25]. Such clusters are also likely to enhance access to more profitable markets by farmers, thereby increasing farmers' bargaining power to secure the best deals for their clusters.

There is evidence that SSA as a whole is already embracing agriculture 4.0-associated technology systems as part of the new wave of the fourth industrial revolution [61] and this offers the continent an opportunity to advance in diverse areas such as climate insurance services provision, agritech-financing, agricultural advisory services provision and farmer-supply chain linkages using blockchain technologies [25,77]. The positive impacts anticipated of this agriculture 4.0 technology adoption include yield increases and a reduction of carbon footprint in line with the Sustainable Development Goals (SDGs), low cost of attracting and maintaining farmers in the supply chain, and price transparency [25].

Adoption of technologies promoted by agriculture 4.0 that lead to improvements in the environment may be particularly relevant for smallholders. For example, adopting agriculture 4.0 technologies for precision agriculture is likely to lead to fertilisers and pesticides being applied in the required doses and concentration, informed by data on the soil condition and nutrient requirements for each crop linked to the weather forecast for rainfall [12]. It is estimated that about $60 \%$ of conventional fertilisers are lost to the environment on application, leading to pollution [14], particularly of water bodies. These agriculture 4.0 technologies, therefore, enable farmers to both reduce their input costs and improve their environmental sustainability. The use of nanofertilisers, an example of nanotechnology precision agriculture, in which nutrients are released slowly resulting in exact dosages [14], also has the potential to improve farm economic and environmental sustainability.

In urban areas, many agriculture 4.0 technologies are associated with the automation of agricultural operations using high-tech solutions [12] supported by well-developed ICT infrastructure, for instance, the rise in wireless communication technologies that use low power wide area network (LPWAN) such as Sigfox, LoRa and NB-IoT [78]. This is not the case in rural areas where smallholders tend to be located [79]. Nevertheless, platform-based ICT and mobile technologies are most suited to the smallholder context and are likely to support SSA with regard to food security and agricultural sustainability [25].

\subsection{Reasons for Caution}

Despite the potential for optimism with regards to agriculture 4.0 in Africa, there are reasons to remain cautious. First, the future of agriculture, as it has been in the past, will be driven by technology and innovation, though increasingly in the context of climate change. Yet despite the challenges affecting SSA's food production and security, the continent's readiness to take advantage of this technology revolution is still in doubt. In many African countries, current levels of investment in critical infrastructure are far below the threshold required for the continent to benefit from the high tech revolution [61]. For example, in the spread of mobile phones for agricultural advisory and banking services, much of SSA could miss out again on another agricultural revolution if the required conditions for adoption such as technology skills are not in place. Moreover, as pressure on the natural environment increases there will similarly be an increasing need for agricultural advances and innovations to be underpinned by good agricultural practices. Agriculture 
4.0 technologies uptake, when done well, should be capable of promoting data-driven agriculture for economically and environmentally sustainable farming. However, these technologies do not exist in a vacuum, and the extent to which agriculture 4.0 does indeed align with sustainable development depends on the broader institutional environment within which relevant technologies are introduced, how they are introduced and taken up.

Second, though the expectation is that agriculture 4.0 technologies will improve agriculture and food security in an efficient and sustainable way, it is possible that these new technologies and ways of working could alter agricultural systems for the worse [80]. For example, increased technology adoption could lead to a disregard of experiential knowledge and disconnect the farmer from the landscape [15], something of potentially particular relevance for SSA agriculture.

Third, several studies focusing on technology adoption have found that despite the significance of technology in improving productivity, unwillingness on the part of farmers to adopt could be a constraint to adoption [7,31]. This could be due to poor awareness, lack of insurance to manage the risks involved in up taking a new idea or lack of skills and knowledge about the appropriateness of technology, as reported by a study conducted in Brazil [59]. Lack of acceptance of technology has also been reported as a barrier to the adoption of agriculture 4.0 technologies in a HIC context [11]. In Nigeria, despite the benefits of agricultural biotechnology advancement in food and non-food production from genetically modified organisms (GMOs) such as pest control and early maturation, the technology has not been accepted due to health, legal and ethical concerns [81].

Fourth, the benefits of this revolution in technology are not likely to be evenly spread across the globe, and it remains uncertain as to with whom and where the benefits will reside [11]. Further, without a clear understanding of how agriculture 4.0 will affect societies, particularly in lower-income countries, these new technologies have the potential to create more problems than they solve due to ethical concerns linked to the deployment of such technology. As such, there is a need for policymakers and technology companies to work together with farmers and communities more broadly in SSA to ensure that the benefits of this suite of technologies are not only optimised for productivity and efficiency but that both environmental and social impacts are addressed explicitly.

\section{Conclusions}

This perspective provides one of the first assessments of agriculture 4.0 that focuses specifically on sub-Saharan Africa. It highlights the key challenges that the continent faces; the extent to which the region is, or is not, ready to embrace this technology revolution and the risks of missing out. It also emphasises the importance of understanding the benefits and potential costs of agriculture 4.0 technologies in the African context; the relationship with the existing diverse agricultural development pathways that focus on sustainable food and agricultural systems [13].

There is an alternative drive to promote agroecology principles that encompass both social and natural sciences that underscore systems philosophy and ecological thinking [13,82]. This is based on the evidence that agroecology practices increase yields in a sustainable and affordable way [22,51]. Whilst agroecology principles have shown great promise for sustainable yield improvement, this approach is likely to be insufficient to meet the food need of the growing SSA population. Therefore it is imperative to identify and adopt suitable technologies that are context-specific and in line with current realities [83].

Author Contributions: Conceptualization, N.P.J., E.J.Z.R. and C.C.O.; resources, N.P.J. and E.J.Z.R.; writing—original draft preparation, N.P.J. and C.C.O.; writing-review and editing, N.P.J., E.J.Z.R. and C.C.O.; supervision, E.J.Z.R.; project administration, N.P.J.; funding acquisition, E.J.Z.R. All authors have read and agreed to the published version of the manuscript.

Funding: This research was funded by UK Research and Innovation through the Global Challenges Research Fund programme, "Growing research capability to meet the challenges faced by developing countries" ("Grow"), grant number ES/P011306/1 and The APC was funded by the University of Reading through the Social and Environmental Trade-Offs in African Agriculture (Sentinel) project. 
Institutional Review Board Statement: Not applicable.

Informed Consent Statement: Not applicable.

Data Availability Statement: Not applicable.

Acknowledgments: Special thanks to the anonymous reviewers for the useful comments on improving this perspective paper; thanks to Beth Downe, International Institute for Environment and Development (IIED) for executive project support.

Conflicts of Interest: The authors declare no conflict of interest. The funders had no role in the design of the study; in the collection, analyses, or interpretation of data; in the writing of the manuscript, or in the decision to publish the results.

\section{References}

1. Meliala, J.; Hubeis, M.; Jahroh, S.; Maulana, A. Position of farmers in agriculture 4.0: Finding from farmers partner of aggregator online vegetables commodity in Indonesia. Arch. Agric. Environ. Sci. 2019, 4, 300-306. [CrossRef]

2. Rapela, M.A. Post-Malthusian Dilemmas in Agriculture 4.0. In Fostering Innovation for Agriculture 4.0: A Comprehensive Plant Germplasm System; Rapela, M.A., Ed.; Springer International Publishing: Cham, Germany, 2019; pp. 1-16.

3. Liu, Y.; Ma, X.; Shu, L.; Hancke, G.P.; Abu-Mahfouz, A.M. From Industry 4.0 to Agriculture 4.0: Current Status, Enabling Technologies, and Research Challenges. IEEE Trans. Ind. Inform. 2021, 17, 4322-4334. [CrossRef]

4. Zhai, Z.; Martínez, J.F.; Beltran, V.; Martínez, N.L. Decision support systems for agriculture 4.0: Survey and challenges. Comput. Electron. Agric. 2020, 170, 105256. [CrossRef]

5. Simpson, J. European Farmers and the British "Agricultural Revolution". In Exceptionalism and Industrialisation: Britain and its European Rivals, 1688-1815; Cambridge University Press: Cambridege, UK, 2004; pp. 69-85. [CrossRef]

6. Rose, D.C.; Chilvers, J. Agriculture 4.0: Broadening Responsible Innovation in an Era of Smart Farming. Front. Sustain. Food Syst. 2018, 2, 87. [CrossRef]

7. Fuglie, K.; Gautam, M.; Goyal, A.; Maloney, W.F. Harvesting Prosperity: Technology and Productivity Growth in Agriculture; Bank, T.W., Ed.; The World Bank: Washington, DC, USA, 2020.

8. Araújo, S.O.; Peres, R.S.; Barata, J.; Lidon, F.; Ramalho, J.C. Characterising the Agriculture 4.0 Landscape-Emerging Trends, Challenges and Opportunities. Agronomy 2021, 11, 667. [CrossRef]

9. Frankelius, P.; Norrman, C.; Johansen, K. Agricultural Innovation and the Role of Institutions: Lessons from the Game of Drones. J. Agric. Environ. Ethics 2019, 32, 681-707. [CrossRef]

10. Klerkx, L.; Jakku, E.; Labarthe, P. A review of social science on digital agriculture, smart farming and agriculture 4.0: New contributions and a future research agenda. NJAS Wagening. J. Life Sci. 2019, 90-91, 100315. [CrossRef]

11. Barrett, H.; Rose, D.C. Perceptions of the Fourth Agricultural Revolution: What's In, What's Out, and What Consequences are Anticipated? Sociol. Rural. 2020. [CrossRef]

12. Cotter, M.; Asch, F. Editorial: Smallholder targeted Agriculture 4.0 in temperature limited cropping systems. J. Agron. Crop Sci. 2020, 206, 421-422. [CrossRef]

13. Klerkx, L.; Rose, D. Dealing with the game-changing technologies of Agriculture 4.0: How do we manage diversity and responsibility in food system transition pathways? Glob. Food Secur. 2020, 24, 100347. [CrossRef]

14. De Clercq, M.; Vats, A.; Biel, A. Agriculture 4.0-The Future of Farming Technology. World Government Summit. Available online: https:/ / www.oliverwyman.com/content/dam/oliver-wyman/v2/publications/2018/February/Oliver-WymanAgriculture-4.0.pdf (accessed on 15 November 2020).

15. Rose, D.C.; Wheeler, R.; Winter, M.; Lobley, M.; Chivers, C.-A. Agriculture 4.0: Making it work for people, production, and the planet. Land Use Policy 2021, 100, 104933. [CrossRef]

16. Hazell, P.B.R. The Asian Green Revolution; International Food Policy Research Institute (IFPRI): Washington, DC, USA, 2009.

17. Das, R.J. The green revolution and poverty: A theoretical and empirical examination of the relation between technology and society. Geoforum 2002, 33, 55-72. [CrossRef]

18. Holmén, H. A Green Revolution for Africa-Does It Need to Be so Controversial? International Centre for Economic Research (ICER): Lund, Sweden, 2003; p. 36.

19. Glaeser, B. The Green Revolution Revisited: Critique and Alternatives; Allen \& Unwin: London, UK, 1987; pp. 1-170.

20. Kariuki, J.G. The Future of Agriculture in Africa, 15th ed.; Najam, A., Barakatt, C., Eds.; Boston University: Boston, MA, USA, 2011.

21. AGRA. Our Story-Alliance for a Green Revolution in Africa (AGRA). Available online: https://agra.org/our-story/ (accessed on 5 January 2021).

22. Wise, T.A. Failing Africa's Farmers: An Impact Assessment of the Alliance for a Green Revolution in Africa; Global Development and Environment Institute, Tufts University: Medford, OR, USA, 2020; p. 38.

23. Jayne, T.S.; Mather, D.; Mghenyi, E. Principal Challenges Confronting Smallholder Agriculture in Sub-Saharan Africa. World Dev. 2010, 38, 1384-1398. [CrossRef]

24. Goyal, A.; Nash, J. Reaping Richer Returns: Public Spending Priorities for African Agriculture Productivity Growth; The World Bank: Washington, DC, USA, 2017. 
25. CTA. The Digitalisation of African Agriculture Report 2018-2019; The Technical Centre for Agricultural and Rural Cooperation (CTA): Wageningen, The Netherlands, 2019; p. 241.

26. Abdallah, A.-H. Does credit market inefficiency affect technology adoption? Evidence from Sub-Saharan Africa. Agric. Financ. Rev. 2016, 76, 494-511. [CrossRef]

27. Lowder, S.K.; Skoet, J.; Raney, T. The Number, Size, and Distribution of Farms, Smallholder Farms, and Family Farms Worldwide. World Dev. 2016, 87, 16-29. [CrossRef]

28. Van Ittersum, M.K.; van Bussel, L.G.J.; Wolf, J.; Grassini, P.; van Wart, J.; Guilpart, N.; Claessens, L.; de Groot, H.; Wiebe, K.; Mason-D'Croz, D.; et al. Can sub-Saharan Africa feed itself? Proc. Natl. Acad. Sci. USA 2016, 113, 14964. [CrossRef]

29. Boko, M.; Niang, I.; Nyong, A.; Vogel, C.; Githeko, A.; Medany, M.; Osman-Elasha, B.; Tabo, R.; Yanda, P. Africa Climate Change 2007: Impacts, Adaptation and Vulnerability: Contribution of Working Group II to the Fourth Assessment Report of the Intergovernmental Panel on Climate Change; IPCC: Cambridge, UK, 2007; pp. 433-467.

30. Jellason, P.N.; Baines, N.R.; Conway, S.J.; Ogbaga, C.C. Climate Change Perceptions and Attitudes to Smallholder Adaptation in Northwestern Nigerian Drylands. Soc. Sci. 2019, 8, 31. [CrossRef]

31. Jellason, N.P.; Conway, J.S.; Baines, R.N. Understanding impacts and barriers to adoption of climate-smart agriculture (CSA) practices in North-Western Nigerian drylands. J. Agric. Educ. Ext. 2020, 27, 55-72. [CrossRef]

32. World Bank. World Development Report 2008: Agriculture for Development; The World Bank: Washington, DC, USA, $2007 ;$ p. 390.

33. Vanlauwe, B.; Coyne, D.; Gockowski, J.; Hauser, S.; Huising, J.; Masso, C.; Nziguheba, G.; Schut, M.; Van Asten, P. Sustainable intensification and the African smallholder farmer. Curr. Opin. Environ. Sustain. 2014, 8, 15-22. [CrossRef]

34. Pretty, J.; Toulmin, C.; Williams, S. Sustainable intensification in African agriculture. Int. J. Agric. Sustain. 2011, 9, 5-24. [CrossRef]

35. Pretty, J.; Bharucha, Z.P. Integrated Pest Management for Sustainable Intensification of Agriculture in Asia and Africa. Insects 2015, 6, 152-182. [CrossRef] [PubMed]

36. Giller, K.E.; Witter, E.; Corbeels, M.; Tittonell, P. Conservation agriculture and smallholder farming in Africa: The heretics' view. Field Crop. Res. 2009, 114, 23-34. [CrossRef]

37. Baudron, F.; Tittonell, P.; Corbeels, M.; Letourmy, P.; Giller, K.E. Comparative performance of conservation agriculture and current smallholder farming practices in semi-arid Zimbabwe. Field Crop. Res. 2012, 132, 117-128. [CrossRef]

38. Vanlauwe, B.; Wendt, J.; Giller, K.E.; Corbeels, M.; Gerard, B.; Nolte, C. A fourth principle is required to define Conservation Agriculture in sub-Saharan Africa: The appropriate use of fertilizer to enhance crop productivity. Field Crop. Res. 2014, 155, 10-13. [CrossRef]

39. Vohland, K.; Barry, B. A review of in situ rainwater harvesting (RWH) practices modifying landscape functions in African drylands. Agric. Ecosyst. Environ. 2009, 131, 119-127. [CrossRef]

40. Mortimore, M.J. Dryland Development: Success Stories from West Africa. Environment 2005, 45, 10-21. [CrossRef]

41. Jellason, N.P.; Conway, J.S.; Baines, R.N.; Ogbaga, C.C. A review of farming challenges and resilience management in the Sudano-Sahelian drylands of Nigeria in an era of climate change. J. Arid. Environ. 2021, 186, 104398. [CrossRef]

42. Whitfield, S.; Dixon, J.L.; Mulenga, B.P.; Ngoma, H. Conceptualising farming systems for agricultural development research: Cases from Eastern and Southern Africa. Agric. Syst. 2015, 133, 54-62. [CrossRef]

43. Chivasa, W.; Mutanga, O.; Biradar, C. Application of remote sensing in estimating maize grain yield in heterogeneous African agricultural landscapes: A review. Int. J. Remote. Sens. 2017, 38, 6816-6845. [CrossRef]

44. Larson, D.F.; Otsuka, K. Introduction: Why an African Green Revolution Is Needed and Why It Must Include Small Farms. In Pursuit of an African Green Revolution; Springer: Tokyo, Japan, 2016; pp. 1-11.

45. Collier, P.; Dercon, S. African Agriculture in 50 years: Smallholders in a Rapidly Changing World? In Proceedings of the Expert Paper for the FAO Conference on "How to Feed the World in 2050?", Rome, Italy, 12-13 October 2009.

46. Bronson, K. Looking through a responsible innovation lens at uneven engagements with digital farming. NJAS Wagening. J. Life Sci. 2019, 90-91, 100294. [CrossRef]

47. Van Zijl, G. Digital soil mapping approaches to address real world problems in southern Africa. Geoderma 2019, 337, 1301-1308. [CrossRef]

48. Hello Tractor. Use Hello Tractor to Make Extra Cash with Your Farm Equipment. Available online: https://hellotractor.com/ (accessed on 1 November 2020).

49. ICRISAT Innovation Hub. Innovation Hub opens for Agri-Tech Entrepreneurs. Available online: https://www.icrisat.org/ innovation-hub-opens-for-agri-tech-entrepreneurs/ (accessed on 1 November 2020).

50. FAO. Digital Innovation for promoting Agriculture 4.0 in the Near East and North Africa. In Proceedings of the FAO Regional Conference for the Near East, Muscat, Oman, 2-4 March 2020.

51. Tittonell, P. Ecological intensification of agriculture-Sustainable by nature. Curr. Opin. Environ. Sustain. 2014, 8, 53-61. [CrossRef]

52. Paliwal, A.; Jain, M. The Accuracy of Self-Reported Crop Yield Estimates and Their Ability to Train Remote Sensing Algorithms. Front. Sustain. Food Syst. 2020, 4, 1-10. [CrossRef]

53. Velasco-Garcia, M.N.; Mottram, T. Biosensors in the livestock industry: An automated ovulation prediction system for dairy cows. Trends Biotechnol. 2001, 19, 433. [CrossRef]

54. Huh, J.-H.; Kim, K.-Y. Time-Based Trend of Carbon Emissions in the Composting Process of Swine Manure in the Context of Agriculture 4.0. Processes 2018, 6, 168. [CrossRef] 
55. Alliance for a Green Revolution in Africa (AGRA). Progress Towards Agricultural Transformation; Alliance for a Green Revolution in Africa (AGRA): Nairobi, Kenya, 2016; pp. 105-124.

56. Kwak, S.-Y.; Wong, M.H.; Lew, T.T.S.; Bisker, G.; Lee, M.A.; Kaplan, A.; Dong, J.; Liu, A.T.; Koman, V.B.; Sinclair, R.; et al. Nanosensor Technology Applied to Living Plant Systems. Annu. Rev. Anal. Chem. 2017, 10, 113-140. [CrossRef]

57. Srivastava, A.K.; Dev, A.; Karmakar, S. Nanosensors and nanobiosensors in food and agriculture. Environ. Chem. Lett. 2018, 16, 161-182. [CrossRef]

58. Lew, T.T.S.; Sarojam, R.; Jang, I.-C.; Park, B.S.; Naqvi, N.I.; Wong, M.H.; Singh, G.P.; Ram, R.J.; Shoseyov, O.; Saito, K.; et al. Species-independent analytical tools for next-generation agriculture. Nat. Plants 2020, 6, 1408-1417. [CrossRef]

59. Bolfe, É.; Jorge, L.; Sanches, I.; Junior, A.; Costa, C.; Victoria, D.; Inamasu, R.; Grego, C.; Ferreira, V.; Ramirez, A. Precision and Digital Agriculture: Adoption of Technologies and Perception of Brazilian Farmers. Agriculture 2020, 10, 653. [CrossRef]

60. Knowler, D.; Bradshaw, B. Farmers' adoption of conservation agriculture: A review and synthesis of recent research. Food Policy 2007, 32, 25-48. [CrossRef]

61. Dosso, M.; Nwankwo, C.I.; Travaly, Y. The Readiness of Innovation Systems for the Fourth Industrial Revolution (4IR) in Sub-Saharan Africa. In Entrepreneurship, Technology Commercialisation, and Innovation Policy in Africa; Daniels, C., Dosso, M., Amadi-Echendu, J., Eds.; Springer International Publishing: Cham, Germany, 2021; pp. 13-32.

62. Wamboye, E.; Tochkov, K.; Sergi, B. Technology Adoption and Growth in sub-Saharan African Countries. Comp. Econ. Stud. 2015, 57, 136-167. [CrossRef]

63. Maree, J.; Piontak, R.; Omwansa, T.; Shinyekwa, I.; Njenga, K. Developmental Uses of Mobile Phones in Kenya and Uganda; Capturing the Gains The University of Manchester: Manchester, UK, 2013; p. 37.

64. Odunze, D.; Mthitwa, H. An Analysis of the Impact of the Use of Mobile Communication Technologies by Farmers in Zimbabwe. A Case Study of Esoko and EcoFarmer Platforms. In Proceedings of the Conversations on Development: Can ICTs Make a Difference in Climate, Political and Health Disturbances? Munster, Germany, 26 May 2015.

65. Van Schalkwyk, F.; Young, A.; Verhulst, S. Esoko-Leveling the Information Playing Field for Smallholder Farmers in Ghana. Available online: https:/ / odimpact.org/files/case-esoko.pdf (accessed on 24 January 2021).

66. Kinchy, A. Seeds, Science, and Struggle: The Global Politics of Transgenic Crops; MIT Press: Cambridge, MA, USA, 2012.

67. Daum, T.; Birner, R. The neglected governance challenges of agricultural mechanisation in Africa-insights from Ghana. Food Secur. 2017, 9, 959-979. [CrossRef]

68. Schut, M.; van Asten, P.; Okafor, C.; Hicintuka, C.; Mapatano, S.; Nabahungu, N.L.; Kagabo, D.; Muchunguzi, P.; Njukwe, E.; Dontsop-Nguezet, P.M.; et al. Sustainable intensification of agricultural systems in the Central African Highlands: The need for institutional innovation. Agric. Syst. 2016, 145, 165-176. [CrossRef]

69. Monteleone, S.; Moraes, E.A.D.; Maia, R.F. Analysis of the variables that affect the intention to adopt Precision Agriculture for smart water management in Agriculture 4.0 context. In Proceedings of the 2019 Global IoT Summit (GIoTS), Aarhus, Denmark, 17-21 June 2019; pp. 1-6.

70. Pogorelskaia, I.; Várallyai, L. Agriculture 4.0 and the role of education. J. Agric. Inform. 2020, 11, 45-51. [CrossRef]

71. Gollin, D.; Lagakos, D.; Waugh, M. Agricultural Productivity Differences across Countries. Am. Econ. Rev. 2014, 104, 165-170. [CrossRef]

72. AUC. Continental Educational Strategy for Africa (CESA) (2016-2025); African Union Commission (AUC): Addis Ababa, Ethiopia, 2016; p. 44.

73. AUC. Science, Technology and Innovation Strategy for Africa (STISA) 2024; African Union Commission (AUC): Addis Ababa, Ethiopia, $2014 ;$ p. 56.

74. AUC. Continental Strategy for Technical and Vocational Education and Training (TVET); African Union Commission (AUC): Addis Ababa, Ethiopia, 2018; p. 40.

75. Tompkins, S. Getting Ready for Agriculture 4.0. Available online: https://www.thestar.com.my/opinion/letters/2020/07/16 / getting-ready-for-agriculture-40 (accessed on 19 November 2020).

76. Joffre, O.M.; Poortvliet, P.M.; Klerkx, L. To cluster or not to cluster farmers? Influences on network interactions, risk perceptions, and adoption of aquaculture practices. Agric. Syst. 2019, 173, 151-160. [CrossRef]

77. AUC. The Digital Transformation Strategy For Africa (2020-2030). Available online: https://au.int/sites/default/files/ documents/38507-doc-dts-english.pdf (accessed on 12 January 2021).

78. Mekki, K.; Bajic, E.; Chaxel, F.; Meyer, F. A comparative study of LPWAN technologies for large-scale IoT deployment. ICT Express 2019, 5, 1-7. [CrossRef]

79. Khaled, S. Are you ready for the Artificial Intelligence in Ag? Western 2020, 2021. Available online: https://www.westernirrigation.com/blog/artificial-intelligence/ (accessed on 28 April 2021).

80. Fielke, S.J.; Garrard, R.; Jakku, E.; Fleming, A.; Wiseman, L.; Taylor, B.M. Conceptualising the DAIS: Implications of the 'Digitalisation of Agricultural Innovation Systems' on technology and policy at multiple levels. NJAS Wagening. J. Life Sci. 2019, 90-91, 100296. [CrossRef]

81. Agozie, E. Nigerian Scientists, Experts Disagree on GM Foods; Premium Times: Abuja, Nigeria, 2019.

82. Francis, C.; Lieblein, G.; Gliessman, S.; Breland, T.A.; Creamer, N.; Harwood, R.; Salomonsson, L.; Helenius, J.; Rickerl, D.; Salvador, R.; et al. Agroecology: The Ecology of Food Systems. J. Sustain. Agric. 2003, 22, 99-118. [CrossRef]

83. Juma, C. The New Harvest: Agricultural Innovation in Africa, 2nd ed.; Oxford University Press: Oxford, UK, 2015. 